\title{
Effects of anti-poaching patrols on the distribution of large mammals in Taï National Park, Côte d'Ivoire
}

\author{
Yves Aka Kablan, Abdoulaye Diarrassouba, Roger Mundry \\ Geneviève Campbell, Emmanuelle Normand, Hualmar S. Kühl \\ InZA Koné and Christophe BOESCH
}

\begin{abstract}
The effectiveness of protected area management is a major concern. In Taï National Park, Côte d'Ivoire, recurrent human pressure challenges the ability of law enforcement authorities to protect wildlife. During 2010-2015 we studied the implementation of law enforcement in the Park to determine (1) the potential for improvement of the protection of large mammals and (2) the minimum patrolling effort needed to obtain increases in their populations. We recorded presence of large mammals and illegal activities in two areas within the Park, the research area $\left(210 \mathrm{~km}^{2}\right)$ and the rest of the Park $\left(5,150 \mathrm{~km}^{2}\right)$, and compiled data about patrolling efforts from the Park authorities. Using a generalized linear mixed model we identified a relationship between increased patrolling effort and the relative abundance of large mammals, especially for monkey groups, pygmy hippopotamuses Choeropsis liberiensis and duikers. At low patrolling efforts duiker encounter rates remained stable, whereas rates of encounter with monkey groups and pygmy hippopotamuses decreased. Chimpanzee Pan troglodytes verus encounter rates were slower to respond and remained stable at higher patrolling effort, but decreased at low patrolling effort. Our findings suggest that a minimum of 1.32 patrol days per $\mathrm{km}^{2}$ over 2 years is required for chimpanzee and monkey populations to increase, whereas a patrolling effort of 0.48 days per $\mathrm{km}^{2}$ over 2 years would lead to an increase in duiker and pygmy hippopotamus populations. We maintain that the
\end{abstract}

Yves AKa Kablan ${ }^{*} \ddagger$ (Corresponding author) and Emmanuelle Normand Wild Chimpanzee Foundation, 23 BP 238 Abidjan 23, Côte d'Ivoire Emailkablan@wildchimps.org

Abdoulaye Diarrassouba† Office Ivoirien des Parcs et Réserves, Abidjan, Côte d'Ivoire

Roger Mundry, Hualmar S. Kühl§ and Christophe Boesch Max Planck Institute for Evolutionary Anthropology, Leipzig, Germany

GeneviÈve CampBell The Biodiversity Consultancy, Cambridge, UK

InZA KonÉł Unité de Formation et de Recherches Biosciences, Université Felix Houphouët Boigny, Abidjan, Côte d'Ivoire

*Also at: Max Planck Institute for Evolutionary Anthropology, Leipzig, Germany $\dagger$ Also at: Unité de Formation et de Recherches Biosciences, Université Felix Houphouët Boigny, Abidjan, Côte d'Ivoire

¥Also at: Centre Suisse de Recherches Scientifiques en Côte d’Ivoire, Abidjan, Côte d'Ivoire

§Also at: German Centre for Integrative Biodiversity Research, Leipzig, Germany

Received 21 April 2017. Revision requested 7 June 2017.

Accepted 4 August 2017. First published online 4 December 2017. patrolling effort required to ensure an increase in wildlife can be estimated relatively precisely from multi-year biomonitoring programmes.

Keywords Conservation effectiveness, Côte d'Ivoire, enforcement, large mammal, patrolling effort, relative abundance, Taï National Park

Supplementary material for this article is available at https://doi.org/10.1017/So030605317001272

\section{Introduction}

The sustainable management of natural resources is a 1 major concern given the rapidly increasing human population and the associated per capita increase in consumption of natural resources (Struhsaker et al., 2005). The threats are particularly important in tropical countries (Whitmore \& Sayer, 1992; Dobson et al., 1997) where management resources are insufficient for effective conservation action (Leader-Williams \& Albon, 1988; Jachmann, 1998). Many conservation biologists and environmentalists agree that the establishment and management of protected areas is an effective way to protect biodiversity (Myers et al., 2000; Bruner et al., 2001; Struhsaker et al., 2005), and since the 1930 s many developing countries have established national parks and nature reserves to prevent exploitation of their natural resources (Leader-Williams \& Albon, 1988). To ensure adherence to restrictions imposed on local communities around protected areas, and increase the effectiveness of protection, law enforcement measures such as ranger patrols are one of the key options adopted (Leader-Williams et al., 1990; Jachmann, 2008a,b; N'Goran et al., 2012; Tranquilli et al., 2012, 2014; Gandiwa et al., 2013; Critchlow et al., 2016). Nevertheless, overexploitation of natural resources occurs in protected areas (Bleher et al., 2006; Hilborn et al., 2006; Gavin et al., 2010; Critchlow et al., 2015) and threatens the survival of some resident animal species (Junker et al., 2012). All the threats to protected areas have a common denominator, namely human population pressure (Harcourt, 1981; Barnes, 1990; Kerr \& Currie, 1995; Bawa \& Dayanandan, 1997; Hoare \& Du Toit, 1999; Muchaal \& Ngandjui, 1999; Robinson et al., 1999; Campbell et al., 2008; Wich et al., 2012), with a continuingly increasing growth rate (Brashares et al., 2001; Wittemyer et al., 2008). Given 
the persistent threat to wildlife, law enforcement effectiveness has been assessed for a number of protected areas, and recommendations provided for its improvement. For example, in the Queen Elizabeth Conservation Area in Uganda, Critchlow et al. $(2015,2016)$ determined the probability of occurrence of various types of illegal activities, and proposed improved patrol strategies to increase the efficiency of detecting illegal activities. Likewise, a study in the Greater Virunga Landscape of Central Africa highlighted a method that can improve law enforcement, resulting in a cost-efficient prevention of illegal activities (Plumptre et al., 2014).

In Côte d'Ivoire no such assessment had been carried out previously, and the level of threat in protected areas, particularly in Taï National Park, remains high, with studies indicating that declines in some mammals, including elephants Loxodonta cyclotis, chimpanzees Pan troglodytes verus and monkeys, are associated with increasing human pressure (Hoppe-Dominik et al., 2011; N'Goran et al., 2012). A law enforcement initiative established in 2006 has suffered from financial difficulties and the post-electoral crisis during 2009-2011, although the presence of research and ecotourism camps in the park has provided some protection for monkey and duiker populations (Köndgen et al., 2008; Campbell et al., 2011; Hoppe-Dominik et al., 2011; N'Goran et al., 2012). In 2010 patrol frequencies were increased in a $210 \mathrm{~km}^{2}$ research area, which has one of the highest densities of primates globally (McGraw et al., 2007), whereas in the rest of the Park the previous level of law enforcement was resumed in 2012 after the post-electoral crisis.

Here we evaluate the relationship between anti-poaching patrols in Taï National Park and the relative abundance of 18 large mammal species: the duikers Philantomba maxwellii, Cephalophus niger, Cephalophus zebra, Cephalophus dorsalis, Cephalophus ogilbyi, Cephalophus jentinki and Cephalophus silvicultor; chimpanzees; pygmy hippopotamuses Choeropsis liberiensis; elephants; and the monkeys Cercopithecus campbelli campbelli, Cercopithecus diana diana, Cercopithecus petaurista buettikoferi, Cercopithecus nictitans stampflii, Cercocebus atys atys, Procolobus verus, Colobus polykomos polykomos and Piliocolobus badius badius. We predicted that the relative abundance of large mammals would increase over time in areas with high patrolling effort compared to areas with low patrolling effort. We also predicted that there would be a minimum patrolling effort necessary to bring about an increase in a taxon's relative abundance. We aim to elucidate the quantitative impact of law enforcement and to offer lessons learned from Taï National Park to facilitate the development of effective biodiversity management policy in protected forest areas throughout the tropics.

\section{Study area}

Taï National Park comprises c. 5,360 $\mathrm{km}^{2}$ of primary forest in the south-west of Côte d'Ivoire (Boesch \& Boesch-
Achermann, 2000; Fig. 1). It was designated a Biosphere Reserve in 1978 and a World Heritage site in 1982 (Allport et al., 1994). Our research area, on the western side of the Park, comprises three research camps associated with the Taï Chimpanzee Project (Boesch \& Boesch-Achermann, 2000) and another associated with the Taï Monkey Project (McGraw et al., 2007), all in close proximity (Fig. 1). The climate is characterized by variable rainfall, with total annual precipitation of 1,400-2,500 mm (Brou, 2009), and mean annual temperature of $24-28^{\circ} \mathrm{C}$; humidity can reach $99 \%$ at night.

\section{Methods}

\section{Sampling design and data collection}

We collected data on mammals (Supplementary Table S1) in the research area during January 2010-March 2015, using $751-\mathrm{km}$ line transects (Fig. 1). Given the difficulty of observing duikers, pygmy hippopotamuses, elephants and chimpanzees directly along transects, we focused on signs of their presence (dung, footprints, nests; Supplementary Material 1). For monkeys, we recorded vocalizations and direct observations. We also recorded evidence of illegal activity along transects. To increase the time interval covered by our analysis we included data collected during September 2008-July 2009 (Campbell et al., 2011).

The Wild Chimpanzee Foundation and l'Office Ivoirien des Parcs et Réserves provided data from the rest of the Park, which were collected on 176 transects (Fig. 1) following the same methods (N'Goran et al., 2012; Supplementary Material 1).

Data on anti-poaching patrols, which occurred during 2006-2015, were extracted from monthly reports of patrol missions conducted by the rangers of Brigade Mobile throughout the Park. From the reports we determined the patrolling effort in the 2-year period prior to each data collection event, and included it in the model as test predictor (Supplementary Material 2).

\section{Other covariates}

We expected the relative abundance of large mammals to be influenced also by other covariates, including ecological factors such as vegetation type and rainfall (White, 1994; Blom et al., 2005), spatial factors such as the distance to the edge of the park and the distance to the research/ecotourism camps (Köndgen et al., 2008; Campbell et al., 2011; Hoppe-Dominik et al., 2011; N'Goran et al., 2012), and the encounter rate of illegal activities (Supplementary Material 3).

\section{Data analysis}

We hypothesized that the relative abundance of all five taxa would be influenced by patrolling effort over time. To test 


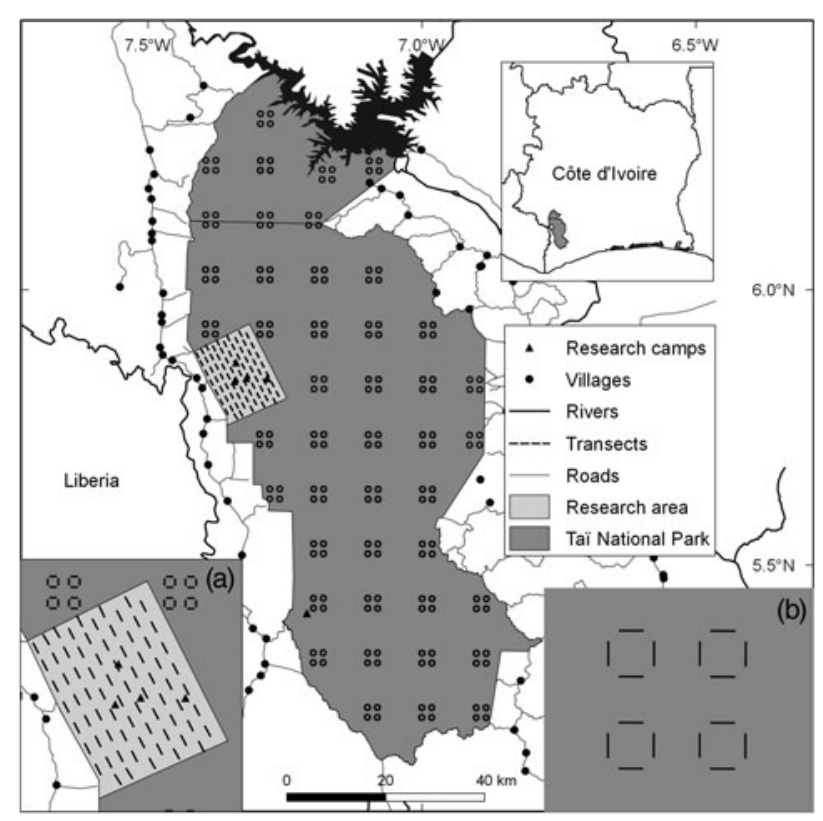

FIG. 1 Locations of transects throughout Taï National Park, Côte d'Ivoire, with (a) the sampling design in the research area, and (b) the design in the rest of the Park.

this hypothesis we fitted a generalized linear mixed model (Baayen, 2008) with Poisson error structure and a log link function (McCullagh \& Nelder, 1989). The model included the three-way interaction between the test predictor (patrolling effort), the predictor 'Julian date' (i.e. the number of days elapsed since 1 January 1970) and the predictor 'species' (factor with five levels: chimpanzee; elephant; pygmy hippopotamus; duikers, all species pooled; and monkeys, all species pooled). The reasoning for including this interaction was that we were interested in understanding how varying levels of patrolling effort affected species' relative abundance over time and how these changes differed among taxa. To control for their potential effects, we included the following in the model: the area type (research area or rest of the Park), the encounter rate of illegal activities, the distance to the border of the Park, the distance to the research/ecotourism camp, the percentage of primary forest, and rainfall (Supplementary Table S2). The transect ID was included as a random effect to account for repeated sampling.

Prior to fitting the model we inspected the distributions of the quantitative predictors, square-root transformed patrolling effort, distances to the border and the camps, and rainfall, and log transformed illegal activity, to avoid skewed distributions and influential cases. To enhance interpretability of the model we subsequently z-transformed all quantitative predictors (including date) to a mean of zero and a standard deviation of one (Aiken et al., 1991; Schielzeth, 2010). To keep the error level at the nominal level of $5 \%$ we fitted the model with an almost maximal random slopes structure (Schielzeth \& Forstmeier, 2009; Barr et al., 2013); i.e. random slopes of patrolling effort, Julian date, species (including their interactions), and illegal activities within transect ID. To include the random slopes of species and the interactions, we manually dummy-coded species and included the dummy variables and products representing the interactions into the random slopes structure of the model (see Supplementary Material 4 for the full model formula). To keep computation time at an acceptable level, we did not include correlations among the random intercept and random slopes components in the model (neglecting such correlations is known not to inflate the type I error rate; Barr et al., 2013). To control for varying transect lengths, we included the lengths of transects (log transformed) as an offset term in the model (McCullagh \& Nelder, 1989). Autocorrelation and collinearity were assessed, and unlikely to hamper inference, and we found the model to be stable (Supplementary Material 4).

We fitted the model in $R$ v. 3.2.o (R Development Core Team, 2015) using the function glmer of the package lme4 (Bates et al., 2015). As an overall test of the effect of the test predictor (patrolling effort) and the interactions in which it was involved, we compared the full model as described above with a null model lacking the fixed effects of patrolling effort, the three-way interaction and also the two-way interactions of patrolling effort with species and with Julian date (Forstmeier \& Schielzeth, 2011; see Supplementary Material 4 for the null model formula), using a likelihood ratio test ( $R$ function anova with argument test set to Chisq) (Dobson, 2002). P-values for the individual effects were based on likelihood ratio tests comparing the full model with a reduced model (Barr et al., 2013) lacking the effect, using the $R$ function dropi. The sample size for this model was 9,015 data points $(1,803$ counts for each taxon on a total of 251 transects walked 4-8 times; median $=7$, mean $=7.2$ ).

We also expected a minimum patrolling effort needed to keep a given species or taxon at a stable encounter rate. To determine this minimum patrolling effort we used parametric bootstrapping of the response based on the model results. The model was identical to the full model with the exception that we excluded all terms (fixed and random effects) including patrolling effort, as this was constant per bootstrapped data set. Conducting 1,000 such bootstraps we were able to determine confidence intervals for the effect of date on encounter rate, for each taxon and for varying levels of patrolling effort (for details see Supplementary Material 4).

\section{Results}

Effects of patrolling effort on the relative abundance of large mammals

During 2008-2015 mean encounter rates of duiker and monkey groups throughout the whole Park were estimated 
to be 6.9 and 2.21 signs per km, respectively. Encounter rates of chimpanzees were 0.99, pygmy hippopotamuses 0.69 , and elephants 0.98 signs per $\mathrm{km}$. The mean patrolling effort in the 2 years prior to each transect survey was calculated to be 0.6 days per $\mathrm{km}^{2}$ during the study period.

Overall, the test predictor 'patrolling effort' had a clear impact on the response variable 'encounter rate' (likelihood ratio test comparing the full model and the null model lacking the test predictor: $\chi^{2}=302.762, \mathrm{df}=10, \mathrm{P}<0.001$ ). More specifically, we found the three-way interaction between patrolling effort, date and species to be clearly significant (likelihood ratio test comparing the full model and the reduced model lacking the interaction: $\chi^{2}=86.95, \mathrm{df}=4, \mathrm{P}<0.001$; Table 1). Inspection of the results revealed that the encounter rate of chimpanzees decreased over time when patrolling effort was low but increased slightly when it was high (Fig. 2). For pygmy hippopotamuses the encounter rate increased over time with higher patrolling effort and decreased with lower patrolling effort (Fig. 2). For elephants the encounter rate increased slightly over time with lower patrolling effort and decreased slightly when patrolling effort was high (Fig. 2). These last two results need to be considered with caution, given the overall low encounter rates. With regard to duikers, encounter rate increased slightly over time when patrolling effort was low and increased clearly over time when it was high. For monkey groups the encounter rate decreased over time when patrolling effort was lower and increased when it was higher (Fig. 2).

Concerning the control predictors, we found that overall encounter rate increased with increasing distance from the Park border, and decreased with increasing distance from the research camp and in areas with higher proportions of primary forest (Table 1). Furthermore, encounter rate decreased with increasing illegal activity, whereas rainfall and area did not have an obvious effect (Table 1).

\section{Thresholds of patrolling effort needed to ensure stabilization or increase of mammal populations}

The bootstrapped estimates for the effect of date, conditional on a particular species and a particular value of patrolling effort, indicated that chimpanzee and monkey group encounter rates decreased significantly over time even with patrolling efforts of up to 0.9 and 0.76 days per $\mathrm{km}^{2}$ per 2 years, respectively, and increased only with patrolling effort of at least 1.32 patrol days per $\mathrm{km}^{2}$ per 2 years (Fig. 3). With regard to duikers, patrolling effort of up to 0.34 days per $\mathrm{km}^{2}$ per 2 years was associated with only a slight, non-significant increase in their encounter rate; however, when patrolling effort increased to at least 0.48 patrol days per $\mathrm{km}^{2}$ per 2 years the encounter rate increased significantly (Fig. 3). For elephants the encounter rate increased significantly even at low patrolling effort of 0.62 days per $\mathrm{km}^{2}$ per 2 years but
TABLE 1 Results of the generalized linear mixed model testing the effect of patrolling effort on large mammal encounter rates in Taï National Park, Côte d'Ivoire (Fig. 1), with estimates and their standard errors from the full model, results of likelihood ratio tests $\left(\chi^{2}\right)$ comparing the full model with a reduced model lacking the relevant term, degrees of freedom, and the $\mathrm{P}$ values from the likelihood ratio test.

\begin{tabular}{|c|c|c|c|c|c|}
\hline Term & Estimate & SE & $\chi^{2}$ & df & $\mathrm{P}^{1}$ \\
\hline Intercept & -7.608 & 0.124 & & & \\
\hline Duikers $^{2}$ & 2.016 & 0.049 & & & \\
\hline $\begin{array}{l}\text { Elephant Loxodonta } \\
\text { cyclotis }^{2}\end{array}$ & -1.951 & 0.184 & & & \\
\hline $\begin{array}{l}\text { Hippopotamus } \\
\quad \text { Choeropsis liberiensis }^{2}\end{array}$ & -0.547 & 0.070 & & & \\
\hline Monkeys $^{2}$ & 0.693 & 0.052 & & & \\
\hline Patrolling effort & 0.148 & 0.048 & & & \\
\hline Julian date & -0.320 & 0.032 & & & \\
\hline Area $^{3}$ & -0.268 & 0.166 & 2.496 & 1 & 0.114 \\
\hline Illegal activities & -0.054 & 0.021 & 6.757 & 1 & 0.009 \\
\hline $\begin{array}{l}\text { Distance to the park } \\
\text { border }\end{array}$ & 0.240 & 0.043 & 28.495 & 1 & $<0.001$ \\
\hline Distance to the camp & -0.433 & 0.071 & 34.312 & 1 & $<0.001$ \\
\hline$\%$ primary forest & 0.199 & 0.051 & 15.411 & 1 & $<0.001$ \\
\hline Rainfall & -0.015 & 0.009 & 2.453 & 1 & 0.117 \\
\hline $\begin{array}{l}\text { Duikers: Patrolling } \\
\text { effort }\end{array}$ & -0.098 & 0.048 & & & \\
\hline $\begin{array}{l}\text { Elephant: Patrolling } \\
\text { effort }\end{array}$ & -0.117 & 0.127 & & & \\
\hline $\begin{array}{l}\text { Hippopotamus: } \\
\text { Patrolling effort }\end{array}$ & -0.669 & 0.068 & & & \\
\hline $\begin{array}{l}\text { Monkeys: Patrolling } \\
\text { effort }\end{array}$ & 0.314 & 0.045 & & & \\
\hline Duikers: Julian date & 0.487 & 0.031 & & & \\
\hline Elephant: Julian date & 0.560 & 0.088 & & & \\
\hline $\begin{array}{l}\text { Hippopotamus: } \\
\text { Julian date }\end{array}$ & 0.679 & 0.048 & & & \\
\hline Monkeys: Julian date & -0.016 & 0.037 & & & \\
\hline $\begin{array}{l}\text { Patrolling effort: } \\
\text { Julian date }\end{array}$ & 0.231 & 0.036 & & & \\
\hline $\begin{array}{l}\text { Duikers: Patrolling } \\
\text { effort: Julian date }\end{array}$ & -0.152 & 0.035 & & & \\
\hline $\begin{array}{l}\text { Elephant: Patrolling } \\
\text { effort: Julian date }\end{array}$ & -0.561 & 0.118 & 86.95 & 4 & $<0.001^{4}$ \\
\hline Hippopotamus: & 0.273 & 0.061 & & & \\
\hline $\begin{array}{l}\text { Patrolling effort: } \\
\text { Julian date }\end{array}$ & & & & & \\
\hline $\begin{array}{l}\text { Monkeys: Patrolling } \\
\text { effort: Julian date }\end{array}$ & 0.042 & 0.039 & & & \\
\hline
\end{tabular}

${ }^{1} \mathrm{P}$ values not indicated for cases in which they had a very limited interpretation

${ }^{2}$ Species was dummy coded, with chimpanzee being the reference category ${ }^{3}$ Dummy coded with research area $=0$ and rest of park $=1$

${ }^{4}$ Overall test of the three-way interaction between species, patrolling effort and Julian date, derived by comparison of the full model with a reduced model lacking the interaction

decreased slightly beyond 0.76 patrol days per $\mathrm{km}^{2}$ per 2 years, although the decrease was not significant (Fig. 3). For pygmy hippopotamuses, the encounter rate decreased significantly at patrolling effort of up to 0.20 patrol days 
(a) Chimpanzees

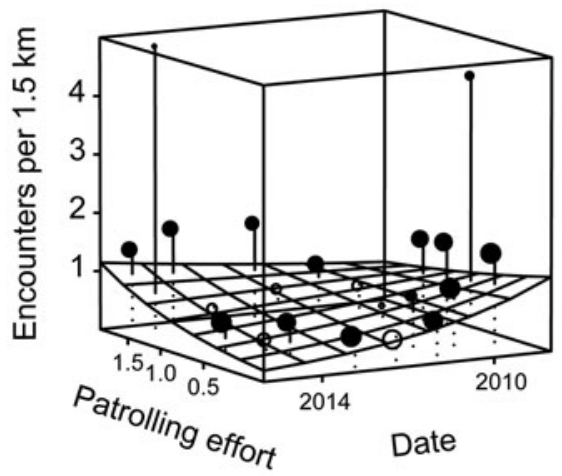

(c) Elephants

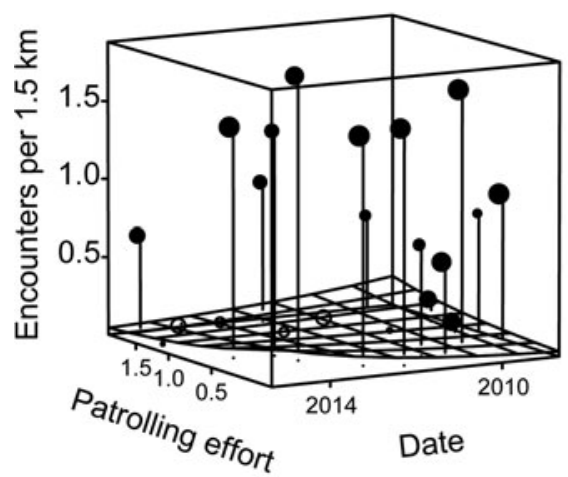

(e) Monkeys

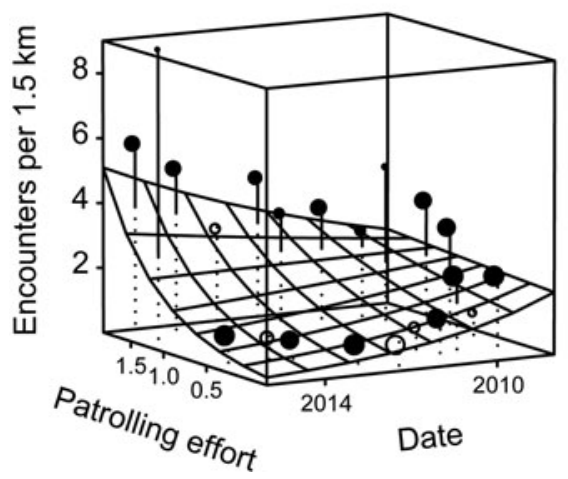

(b) Duikers

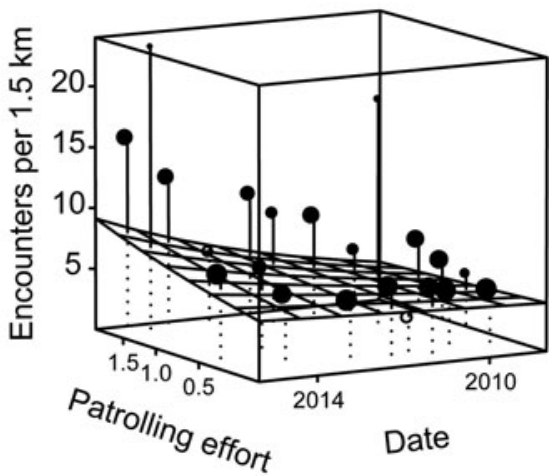

(d) Pygmy hippopotamuses

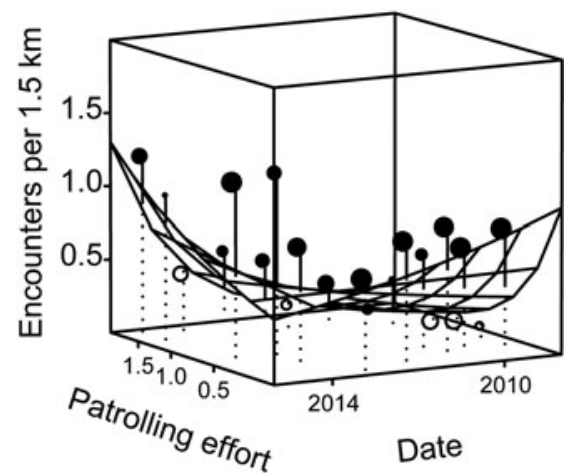

FIG. 2 Change in encounter rates of (a) chimpanzees Pan troglodytes verus, (b) duikers (seven species), (c) elephants Loxodonta cyclotis, (d) pygmy hippopotamuses Choeropsis liberiensis and (e) monkeys (eight species) in Taï National Park, Côte d'Ivoire (Fig. 1) during 2008-2015, as a function of patrolling effort (patrol days per $\mathrm{km}^{2}$ per 2 years), with the fitted model (gridded surface) and the mean number of encounters per $1.5 \mathrm{~km}$ transect per cell of the gridded surface. Encounter rates above the surface are indicated with filled circles and those below the surface with unfilled circles. The size of the circles is proportionate to the number of transects with the same combination of patrolling effort and time $(\mathrm{N}=1-$ 183 transects per cell). per $\mathrm{km}^{2}$ per 2 years but increased significantly beyond 0.48 patrol days per $\mathrm{km}^{2}$ per 2 years (Fig. 3).

\section{Discussion}

The key aspect of our study was to determine how patrolling effort affected the relative abundance of large mammals both spatially and temporally. We found that frequent active patrols in the Park had a positive effect, confirming the effectiveness of this conservation intervention. We found that changes in encounter rates of the focal taxa/species over time depended on patrolling effort, and that the particular pattern of this dependency, in relation to their life history traits and sensitivity to human pressure, varied between the five taxa.

Chimpanzee encounter rates decreased over time in areas where patrolling effort was relatively low, and stabilized only at higher patrolling effort, highlighting the vulnerability of this species in areas that are less protected, and subject to a high level of human pressure (Kormos et al., 2003; Campbell et al., 2008; Hicks et al., 2009; Tranquilli et al., 2012; 

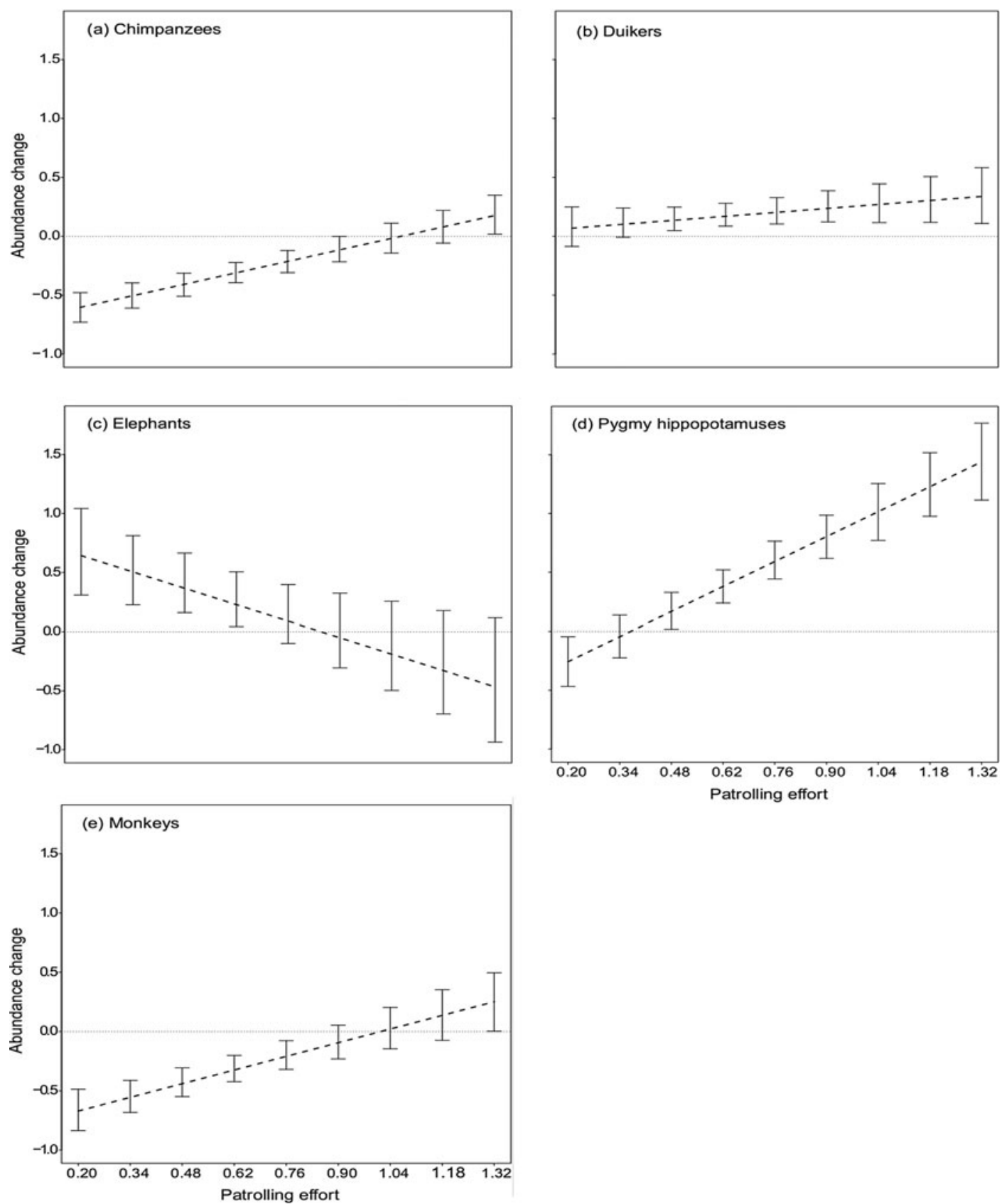

FIG. 3 Change in relative abundance of (a) chimpanzees Pan troglodytes verus, (b) duikers (seven species), (c) elephants Loxodonta cyclotis, (d) pygmy hippopotamuses Choeropsis liberiensis and (e) monkeys (eight species) in Taï National Park, Côte d'Ivoire (Fig. 1) during 2008-2015, as a function of patrolling effort (patrol days per $\mathrm{km}^{2}$ per 2 years). Negative values along the $y$-axis indicate that the relative abundance decreased over time. The point at which the dashed line intersects the horizontal line indicates the patrolling effort at which the change in relative abundance shifted from negative to positive. The results of the bootstrap are shown by the error bars: these indicate the confidence interval of the effect on the relative abundance over time for a given patrolling effort. Where these confidence intervals do not overlap the horizontal line, the effect of patrolling effort on relative abundance is significant.

N'Goran et al., 2013; Tweh et al., 2015). Given the species' low reproductive rate, any demographic shock caused by poaching will have a long-lasting effect on the size of the population. In Taï National Park, for example, the mean age of chimpanzees at first parturition is 13.8 years and the mean inter-birth interval is 5.9 years, with one infant per birth (Boesch \& Boesch-Achermann, 2000). Thus, more effort over a longer time period than the study duration would be necessary to evaluate the precise rate of population recovery and to observe a positive change in relative abundance. The bootstrapping results indicate that a minimum of 1.32 patrol days per $\mathrm{km}^{2}$ per 2 years is required to induce an increase in chimpanzee encounter rate. However, the mean patrolling effort for the whole Park was 0.6 days per $\mathrm{km}^{2}$ per 2 years. This suggests that if 
the patrolling effort remains the same the chimpanzee population will continue to decrease. We therefore recommend that the patrolling effort be increased by 2.2 times to ensure the persistence of the chimpanzee population.

In contrast, we found pygmy hippopotamuses required less patrol effort for population stability. Bootstrapping results indicated that a minimum effort of 0.48 days per $\mathrm{km}^{2}$ per 2 years would suffice to ensure a population increase, suggesting that this species will remain stable if patrolling continues at the current level. The pygmy hippopotamus is difficult to hunt, given its relatively low population density and cryptic behaviour, and difficult to carry over long distances, as attested by some hunters. Taï National Park is home to at least $50 \%$ of the global pygmy hippopotamus population (Roth et al., 2004).

The results for elephants contradicted our predictions, indicating a slight decrease in encounter rate with high patrolling effort, although it was not significant. The rarity of data could be a factor limiting the interpretation of this result. Another probable explanation is that the elephant population density is too low to make hunting them worthwhile. This would explain why the presence of poachers or rangers had so little effect. During 2006-2008 an encounter rate of 0.839 signs per $\mathrm{km}$ was estimated for the whole Park (N'Goran, 2015). Our estimation during the study period was 0.986 signs per $\mathrm{km}$, confirming the stability of this species, but at a low encounter rate. Moreover, N'Goran (2015) found the population to be unevenly distributed, with elephants occurring in the centre and south-west of the Park only, and no evidence of their presence in the north and east, which have experienced long-term hunting pressure (Allport et al., 1994; Boesch \& Boesch-Achermann, 2000). Even in the research area, where other mammals benefit from the long-term presence of researchers (Köndgen et al., 2008; Campbell et al., 2011; N'Goran et al., 2012), elephant signs were found at a low relative abundance ( 0.27 signs per $\mathrm{km}$ ) throughout the study period.

Duikers and monkeys, the most abundant large mammals in the Park, were affected positively by patrolling effort, as predicted. The monkey encounter rate decreased and the duiker encounter rate remained stable when patrolling effort was low, but both increased with higher patrolling effort. Our bootstrapping results show that monkeys (1.32 patrol days per $\mathrm{km}^{2}$ per 2 years) required 2.75 times more patrolling effort than duikers ( 0.48 patrol days per $\mathrm{km}^{2}$ per 2 years) before showing an increase in encounter rate. This could be attributable to a difference in susceptibility to hunting between the two taxa. Monkeys live in diurnally active social groups that make considerable noise, making them easily detectable, whereas duikers are mostly solitary, and secretive, and hence more difficult to hunt (Bodmer et al., 1988; Fitzgibbon et al., 1995; Muchaal \& Ngandjui, 1999; Lwanga, 2006). This logic is supported by our finding of similar patterns in terms of the relationship between patrolling effort and encounter rates for chimpanzees and monkeys, both of which taxa are diurnal, social and gregarious. The variation in techniques used to hunt monkeys and duikers is probably driven by these differences in behaviours. Duikers are hunted mostly at night (because of their predominantly nocturnal activity patterns) using shotguns and most often snares (Noss, 1998a,b; Wilkie \& Carpenter, 1999; Bahuchet, 2000; Kümpel, 2006), whereas monkeys are hunted most often during the day using shotguns (Bahuchet, 2000; Kümpel, 2006; Kümpel et al., 2008). This suggests that limited diurnal patrolling may be more effective in removing snares placed at night than deterring day-time hunting with shotguns. It is important to consider the dynamics of hunting pressure, which is likely to respond to the temporal and spatial patterns of patrols. The availability of mobile phone technology in the region has exacerbated this problem by facilitating the rapid relaying of information among poachers, and thus helping them to avoid law enforcement patrols. Another point to highlight is that the high reproduction rate of some duiker species means they can adapt and maintain their population viability in threatened areas (e.g. the blue duiker Philantomba monticola in Kibale National Park, Uganda; Hart, 2000; Lwanga, 2006). Hence, monkey populations seem to be more affected than duikers in areas with low patrolling effort. The current level of patrolling effort throughout Taï National Park is sufficient to ensure an increase in the duiker populations, but not for the eight species of diurnal monkeys, which would require a patrolling effort similar to that needed to ensure an increase in the chimpanzee population.

Our results also indicated other factors that influenced the relative abundance of large mammals. The presence of research and tourist camps was found to have a positive effect, whereas illegal activities had a negative effect, as shown in previous studies (Campbell et al., 2011; Hoppe-Dominik et al., 2011; N'Goran et al., 2012). However, despite the apparent positive effect, research and ecotourism camps could also make some large mammals more vulnerable because of their habituation to human presence, and increase the risk of disease transmission between people and wildlife (Köndgen et al., 2008) if appropriate measures are not undertaken. The distance from the edge of the forest was also found to influence mammal distribution (Campbell et al., 2011). Most of the large mammals were more common in the core of the Park than on the periphery. However, this result is not supported by findings from Katavi National Park, in Tanzania (Kiffner et al., 2013). An important distinction in the case of Taï National Park, however, is that the eastern edge was degraded in the 198 os by plantations. At the start of the study period most of these plantations had already been abandoned following an earlier intervention by the Park authorities, which led to the restoration of bush and herbaceous vegetation. Our model has shown that encounter rates for large mammals were high in areas with a high proportion of primary forest, as reported by Hoppe-Dominik 
et al. (2011), and were similar in the research area and the rest of the Park, as well as in the rainy and dry seasons.

Overall, our findings indicate that the permanent presence of rangers in the Park is critical to protect wildlife populations and keep illegal activities under control. Given that most studies dealing with law enforcement effectiveness are long-term studies (Leader-Williams et al., 1990; Hilborn et al., 2006; Gandiwa et al., 2013), we recommend the continuation of the ecological monitoring project to assess the ability of large mammals to repopulate areas where their abundance has declined, in response to adjustment of the patrol effort.

Our findings also indicate that if patrolling effort is not high enough, wildlife populations will continue to decrease in the face of increasing human pressures. However, we also believe that other factors, such as changing people's behaviour through awareness raising, are also important to consider for wildlife protection (Kouassi et al., 2017). We have used a novel approach, collecting data on wildlife and illegal activity independently of patrolling data; however, the measure we used to estimate patrolling effort is coarse and does not take into account the precise location of patrols. We had planned to use global positioning system track-logs as a proxy for patrolling effort, but these were removed from the analyses because of errors and inconsistencies in application by some rangers during patrols. Moreover, the detection probability of species was not addressed explicitly, which could potentially lead to biases. However, we believe that the independence of the two types of data collected and the randomness of transects taken into account in the analysis support the reliability of our inferences. We emphasize the necessity for sufficiently high patrolling effort to ensure the stability of species with low reproductive rates (e.g. chimpanzees) and species facing high hunting pressure (e.g. diurnal monkeys). The situation will vary among protected areas, however, depending on the unique dynamics of the species community and the targets and intensity of hunting pressure.

\section{Acknowledgements}

We thank the Ministère de l'environnement et du développement durable, the Ministère de l'enseignement supérieur et de la recherche scientifique, and Université Felix Houphouët Boigny. We also thank l'Office Ivoirien des Parcs et Réserves and its Director, Mr Adama Tondossama, for permission to conduct this work; the United Nations Development Programme, the Max Planck Society, the Wild Chimpanzee Foundation, Centre Suisse de Recherches Scientifiques and the Robert Bosch Foundation, for funding and technical support; Ilka Herbinger, Paul N'Goran, Celestin Kouakou, Charlène Régnier, Noémie Capelle, Mimi Arandjelovic, Joseph Kouassi and Jack Lester, for their help and advice; our assistants for their help during data collection; and the anonymous reviewers for their valuable comments.

\section{Author contributions}

YAK implemented the project, collected and analysed data, interpreted and discussed the results and wrote the article. $\mathrm{AD}$ contributed to the implementation of the project, the data collection and the revision of the manuscript. RM contributed to the statistical analysis, the interpretation of results and the writing and revision of the manuscript. GC contributed to the project implementation, the data collection and the revision of the manuscript. EN conceived and contributed to the implementation of the project and the revision of the manuscript. HSK, IK and CB conceived and revised the project protocol and contributed to the structure, writing and revision of the manuscript.

\section{References}

Aiken, L.S., West, S.G. \& Reno, R.R. (1991) Multiple Regression: Testing and Interpreting Interactions. Sage Publications, Thousand Oaks, USA.

Allport, G., Boesch, C., Couturier, G., Esser, J., Merz, G. \& Piart, J. (1994) La faune. In Le Parc National de Tä̈, Côte d'Ivoire. Synthèse des connaissances (eds E.P. Reizebos \& J.L. Guillaumet), pp. 72-93. Tropenbos Series 8, Wageningen, Netherlands.

B Aayen, R.H. (2008) Analyzing Linguistic Data: A Practical Introduction to Statistics using R. Cambridge University Press, Cambridge, UK.

B A huchet, S. (200o) La Filière 'Viande de Brousse'. In Les Peuples des forêts tropicales aujourd'hui: Une approche thématique (ed. S. Bahuchet), pp. 331-363. Programme Avenir des Peuples des Forêts Tropicales, Brussels, Belgium.

BARnes, R.F.W. (1990) Deforestation trends in tropical Africa. African Journal of Ecology, 28, 161-173.

Barr, D.J., Levy, R., Scheepers, C. \& Tily, H.J. (2013) Random effects structure for confirmatory hypothesis testing: keep it maximal. Journal of Memory and Language, 68, 255-278.

Bates, D., Mächler, M., Bolker, B.M. \& Walker, S.C. (2015) Fitting linear mixed-effects models using lme4. Journal of Statistical Software, 67, 1-48.

BAWA, K.S. \& Dayanandan, S. (1997) Socioeconomic factors and tropical deforestation. Nature, 386, 562-563.

Bleher, B., Uster, D. \& Bergsdorf, T. (2006) Assessment of threat status and management effectiveness in Kakamega Forest, Kenya. Biodiversity and Conservation, 15, 1159-1177.

Blom, A., van Zalinge, R., Heitkönig, I.M.A. \& Prins, H.H.T. (2005) Factors influencing the distribution of large mammals within a protected central African forest. Oryx, 39, 381-388.

Bodmer, R.E., Fang, T.G. \& Ibanez, L.M. (1988) Primates and ungulates: a comparison of susceptibility to hunting. Primate Conservation, 9, 79-83.

Boesch, C. \& Boesch-Achermann, H. (2000) The Chimpanzees of the Taï Forest: Behavioural Ecology and Evolution. Oxford University Press, Oxford, UK.

Brashares, J.S., Arcese, P. \& SAm, M.K. (2001) Human demography and reserve size predict wildlife extinction in West Africa. Proceedings of the Royal Society B, 268, 2473-2478.

Brou, Y.T. (2009) Impacts des modifications bioclimatiques et des l'amenuisement des terres forestières dans les paysanneries ivoiriennes: quelles solutions pour une agriculture durable en Côte d'Ivoire. Cuadernos Geograficos, 45, 13-29. 
Bruner, A.G., Gullison, R.E., Rice, R.E. \& da Fonseca, G.A.B. (2001) Effectiveness of parks in protecting tropical biodiversity. Science, 291, 125-128.

Buckland, S.T., Anderson, D.R., Burnham, K.P., LaAke, J.L., Borchers, D.L. \& Thomas, L. (2001) Introduction to Distance Sampling: Estimating Abundance of Biological Populations. Oxford University Press, Oxford, UK.

Campbell, G., Kuehl, H., Diarrassouba, A., N'Goran, P.K. \& BoEsch, C. (2011) Long-term research sites as refugia for threatened and over-harvested species. Biology Letters, 7, 723-726.

Campbell, G., Kuehl, H., N'Goran, K.P. \& Boesch, C. (2008) Alarming decline of West African chimpanzees in Côte d'Ivoire. Current Biology, 18, 903-904.

Critchlow, R., Plumptre, A.J., Alidria, B., Nsubuga, M., Driciru, M., Rwetsiba, A. et al. (2016) Improving law-enforcement effectiveness and efficiency in protected areas using ranger-collected monitoring data. Conservation Letters, http://dx.doi.org/10.1111/conl.12288.

Critchlow, R., Plumptre, A.J., Driciru, M., Rwetsiba, A., Stokes, E.J., Tumwesigye, C. et al. (2015) Spatiotemporal trends of illegal activities from ranger-collected data in a Ugandan national park. Conservation Biology, 29, 1458-1470.

Dobson, A.J. (2002) An Introduction to Generalized Linear Models. 2nd edition. Chapman \& Hall/CRC Press, New York, USA.

Dobson, A.P., Bradshaw, A.D. \& BAKER, A.J.M. (1997) Hopes for the future: restoration ecology and conservation biology. Science, 277, 515-522.

Estes, R.D. (1991) The Behavior Guide to African Mammals: Including Hoofed Mammals, Carnivores, Primates. University of California Press, Berkeley, USA.

Fitzgibbon, C.D., Mogaka, H. \& Fanshawe, J.H. (1995) Subsistence hunting in Arabuko-Sokoke Forest, Kenya, and its effects on mammal populations. Conservation Biology, 9, 1116-1126.

Forstmeier, W. \& Schielzeth, H. (2011) Cryptic multiple hypotheses testing in linear models: overestimated effect sizes and the winner's curse. Behavioral Ecology and Sociobiology, 65, $47-55$.

Fox, J. \& Monette, G. (1992) Generalized collinearity diagnostics. Journal of the American Statistical Association, 87, 178-183.

Fox, J. \& Weisberg, S. (2011) An R Companion to Applied Regression. and edition. Sage Publications, Thousand Oaks, USA.

Gandiwa, E., Heit König, I.M.A., Lokhorst, A.M., Prins, H.H.T. \& LeEuwis, C. (2013) Illegal hunting and law enforcement during a period of economic decline in Zimbabwe: a case study of northern Gonarezhou National Park and adjacent areas. Journal for Nature Conservation, 21, 133-142.

Gavin, M.C., Solomon, J.N. \& Blank, S.G. (2010) Measuring and monitoring illegal use of natural resources. Conservation Biology, 24, 89-100.

HarCourt, A.H. (1981) Can Uganda's gorillas survive?-A survey of the Bwindi Forest Reserve. Biological Conservation, 19, 269-282.

HART, J. (2000) Impact and sustainability of indigenous hunting in the Ituri Forest, Congo-Zaire: a comparison of unhunted and hunted duiker populations. In Hunting for Sustainability (eds J. Robinson \& E. Bennett), pp. 106-153. Columbia University Press, New York, USA.

Hicks, T.C., Fouts, R.S. \& Fouts, D.H. (2009) A survey of chimpanzees (Pan troglodytes troglodytes) and gorillas (Gorilla gorilla gorilla) in the selectively logged Ngotto Forest, Central African Republic. Journal of Applied Animal Welfare Science, 12, 165-188.

Hilborn, R., Arcese, P., Borner, M., Hando, J., Hopcraft, G., Lоівоокі, M. et al. (2006) Effective enforcement in a conservation area. Science, 314, 1266.

Hoare, R.E. \& Du Toit, J.T. (1999) Coexistence between people and elephants in African savannas. Conservation Biology, 13, 633-639.
Hoppe-Dominik, B., KÜhl, H.S., RadL, G. \& Fischer, F. (2011) Long-term monitoring of large rainforest mammals in the Biosphere Reserve of Taï National Park, Côte d'Ivoire. African Journal of Ecology, 49, 450-458.

Huffman, B. (2016) Http://www.ultimateungulate.com [accessed 25 September 2016].

IUCN (2016) The IUCN Red List of Threatened Species. Http://www. iucnredlist.org [accessed 1o October 2016].

JaChmann, H. (1998) Monitoring Illegal Wildife Use and Law Enforcement in African Savanna Rangelands. Environmental Council of Zambia Publication, Lusaka, Zambia.

JaChmann, H. (2008a) Monitoring law-enforcement performance in nine protected areas in Ghana. Biological Conservation, 141, 89-99.

JACHmann, H. (2008b) Illegal wildlife use and protected area management in Ghana. Biological Conservation, 141, 1906-1918.

Junker, J., Blake, S., Boesch, C., Campbell, G., Du Toit, L., Duvall, C. et al. (2012) Recent decline in suitable environmental conditions for African great apes. Diversity and Distributions, 18, 1077-1091.

Kerr, J.T. \& CURrie, D.J. (1995) Effects of human activity on global extinction risk. Conservation Biology, 9, 1528-1538.

Kiffner, C., Stoner, C. \& Caro, T. (2013) Edge effects and large mammal distributions in a national park. Animal Conservation, 16 , 97-107.

Köndgen, S., Kühl, H., N'Goran, P.K., Walsh, P.D., Schenk, S., Ernst, N. et al. (2008) Pandemic human viruses cause decline of endangered great apes. Current Biology, 18, 260-264.

Kormos, R., Boesch, C., Bakarr, M.I. \& Butynski, T.M. (eds) (2003) Status Survey and Conservation Action Plan: West African Chimpanzees. IUCN/SSC Primate Specialist Group, Gland, Switzerland, and Cambridge, UK.

Kouakou, C.Y., Boesch, C. \& Kuehl, H. (2009) Estimating chimpanzee population size with nest counts: validating methods in Taï National Park. American Journal of Primatology, 71, 447-457.

Kouassi, J.A.K., Normand, E., Koné, I. \& Boesch, C. (2017) Bushmeat consumption and environmental awareness in rural households: a case study around Taï National Park, Côte d'Ivoire. Oryx, https://doi.org/10.1017/So030605317000333.

Kühl, H., Maisels, F., Ancrenaz, M. \& Williamson, E.A. (2008) Best Practice Guidelines for Surveys and Monitoring of Great Ape Populations. IUCN SSC Primate Specialist Group, Gland, Switzerland.

Kümpel, N.F. (2006) Incentives for sustainable hunting of bushmeat in Río Muni, Equatorial Guinea. $\mathrm{PhD}$ thesis. Imperial College London, UK.

Kümpel, N.F., Milner-Gulland, E.J., Rowcliffe, J.M. \& Cowlishaw, G. (2008) Impact of gun-hunting on diurnal primates in continental Equatorial Guinea. International Journal of Primatology, 29, 1065-1082.

Leader-Williams, N. \& Albon, S.D. (1988) Allocation of resources for conservation. Nature, 336, 533-535.

Leader-Williams, N., Albon, S.D. \& Berry, P.S.M. (1990) Illegal exploitation of black rhinoceros and elephant populations: patterns of decline, law enforcement and patrol effort in Luangwa Valley, Zambia. Journal of Applied Ecology, 27, 1055-1087.

LWANGA, J.S. (2006) The influence of forest variation and possible effects of poaching on duiker abundance at Ngogo, Kibale National Park, Uganda. African Journal of Ecology, 44, 209-218.

Manly, B. (1997) Randomization, Bootstrap and Monte Carlo Methods in Biology. Chapman \& Hall, New York, USA.

McCullagh, P. \& Nelder, J.A. (1989) Generalized Linear Models. and edition, Chapman \& Hall, New York, USA.

McGraw, W.S., Zuberbühler, K. \& Noe, R. (eds) (2007) Monkeys of the Taï Forest: An African Primate Community. Cambridge University Press, New York, USA. 
MuchaAl, P.K. \& NGandjui, G. (1999) Impact of village hunting on wildlife populations in the western Dja Reserve, Cameroon. Conservation Biology, 13, 385-396.

Mundry, R. (2014) Statistical issues and assumptions of phylogenetic generalized least squares. In Modern Phylogenetic Comparative Methods and Their Application in Evolutionary Biology (ed. L.Z. Garamszegi), pp. 131-153. Springer, Heidelberg, Germany.

Myers, N., Mittermeier, R.A., Mittermeier, C.G., Da Fonseca, G.A.B. \& KenT, J. (2000) Biodiversity hotspots for conservation priorities. Nature, 403, 853-858.

N'Goran, K.P. (2015) Suivi écologique intégré pour une gestion durable des aires protégées de Côte d'Ivoire: Cas des parcs nationaux de Tai (Sud-Ouest) et de Marahoué (Centre). $\mathrm{PhD}$ thesis. Université Nangui Abrogoua, Abidjan, Côte d'Ivoire.

N'Goran, P.K., Boesch, C., Mundry, R., N'Goran, E.K., Herbinger, I., Yapi, F.A. \& KüHL, H.S. (2012) Hunting, law enforcement, and African primate conservation. Conservation Biology, 26, 565-571.

N'Goran, P.K., Kouakou, C.Y., N'goran, E.K., Konaté, S., Herbinger, I., Yapi, F.A. et al. (2013) Chimpanzee conservation status in the World Heritage Site Tai National Park, Côte d'Ivoire. International Journal of Innovation and Applied Studies, 3 , 326-336.

Noss, A.J. (1998a) Cable snares and bushmeat markets in a central African forest. Environmental Conservation, 25, 228-233.

Noss, A.J. (1998b) The impacts of cable snare hunting on wildlife populations in the forests of the Central African Republic. Conservation Biology, 12, 390-398.

Plumptre, A.J., Fuller, R.A., Rwetsiba, A., Wanyama, F., Kujirakwinja, D., Driciru, M. et al. (2014) Efficiently targeting resources to deter illegal activities in protected areas. Journal of Applied Ecology, 51, 714-725.

R Development Core Team (2015) R: A Language and Environment for Statistical Computing. R Foundation for Statistical Computing, Vienna, Austria.

Robinson, J.G., Redford, K.H. \& Bennett, E.L. (1999) Wildlife harvest in logged tropical forests. Science, 284, 595-596.

Ross, C. (1991) Life history patterns of new world monkeys. International Journal of Primatology, 12, 481-502.

Roth, H.H., Hoppe-Dominik, B., Mühlenderg, M., SteinhauerBurkart, B. \& Fischer, F. (2004) Distribution and status of the hippopotamids in the Ivory Coast. African Zoology, 39, 211-224.

Rowe, N. (1996) The Pictorial Guide to the Living Primates. Pogonias Press, East Hampton, USA.

Schielzeth, H. (2010) Simple means to improve the interpretability of regression coefficients. Methods in Ecology and Evolution, 1, 103-113.

Schielzeth, H. \& Forstmeier, W. (2009) Conclusions beyond support: overconfident estimates in mixed models. Behavioral Ecology, 20, 416-420.

Scholte, P., Adam, S. \& Serge, B.K. (2007) Population trends of antelopes in Waza National Park (Cameroon) from 1960 to 2001: the interacting effects of rainfall, flooding and human interventions. African Journal of Ecology, 45, 431-439.
Struhsaker, T.T., Struhsaker, P.J. \& Siex, K.S. (2005) Conserving Africa's rain forests: problems in protected areas and possible solutions. Biological Conservation, 123, 45-54.

Thomas, L., Laake, J., Rexstad, E., Strindberg, S., Marques, F., Buckland, S. et al. (2009) Distance 6.o. Release 2. Research Unit for Wildlife Population Assessment. University of St. Andrews, United Kingdom. Http://www.ruwpa.st-and.ac.uk/distance/.

Tranquilli, S., Abedi-Lartey, M., Abernethy, K., Amsini, F., Asamoah, A., Balangtaa, C. et al. (2014) Protected areas in tropical Africa: assessing threats and conservation activities. PLoS ONE, 9(12), e114154.

Tranquilli, S., Abedi-Lartey, M., Amsini, F., Arranz, L., Asamoah, A., BabAfemi, O. et al. (2012) Lack of conservation effort rapidly increases African great ape extinction risk. Conservation Letters, 5, 48-55.

Tweh, C.G., Lormie, M.M., Koua kou, C.Y., Hillers, A., Kühl, H.S. \& Junker, J. (2015) Conservation status of chimpanzees Pan troglodytes verus and other large mammals in Liberia: a nationwide survey. Oryx, 49, 710-718.

White, L.J.T. (1994) Biomass of rain forest mammals in the Lopé Reserve, Gabon. Journal of Animal Ecology, 63, 499-512.

Whitmore, T. \& S Ayer, J. (eds) (1992) Tropical Deforestation and Species Extinction. Chapman \& Hall, London, UK.

Wich, S.A., Fredriksson, G.M., Usher, G., Peters, H.H., Priatna, D., BASAlamaH, F. et al. (2012) Hunting of Sumatran orangutans and its importance in determining distribution and density. Biological Conservation, 146, 163-169.

Wilkie, D.S. \& Carpenter, J.F. (1999) Bushmeat hunting in the Congo Basin: an assessment of impacts and options for mitigation. Biodiversity and Conservation, 8, 927-955.

Wittemyer, G., Elsen, P., Bean, W.T., Burton, A.C.O. \& Brashares, J.S. (2008) Accelerated human population growth at protected area edges. Science, 321, 123-126.

\section{Biographical sketches}

YVES AKA KabLAN's research focuses on the assessment of conservation activities, monitoring of wildlife, and management of protected areas. Abdoulaye Diarrassouba is interested in the management of protected areas, and is the manager of Taï National Park. Roger MUNDRY is a biologist with an interest in statistics and computational methods. Geneviève CAMPBell is an expert in biodiversity conservation issues, with experience in primate and large mammal surveys. EMMANUELLE NORMAND is interested in biodiversity conservation, protected area management and environmental education. HJALMAR KÜHL is interested in ape conservation and the development of wildlife survey and monitoring techniques. In ZA KonÉ is a primatologist. He is an expert in conservation biology, environmental education and community empowerment. CHRISTOPHE $\mathrm{BOESCH}$ is a primatologist with interests in various aspects of the biology of chimpanzees and the evolution of their cognitive and cultural abilities. He also focuses on biodiversity conservation issues. 